\title{
ЯКІСТЬ ВИЩОÏ ОСВІТИ В УКРАЇНІ ОЧИМА СТУДЕНТІВ
}

\section{https://doi.org/10.37472/2707-305X-2021-3-2-11-5}

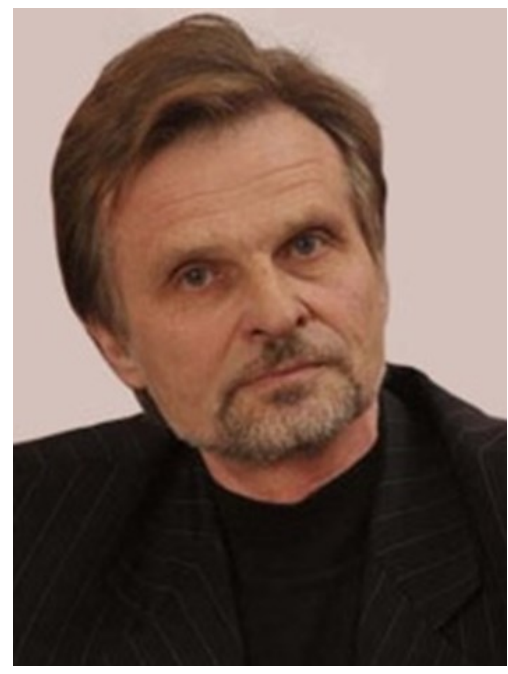

\section{САУХ Петро Юрійович}

доктор фрілософських наук, профресор, дійсний член (академік) НАПН України, академік-секретар Відділення вищої освіти Начіональної академії педагогічних наук України, м. Київ, Україна

\section{(iD) $\curvearrowright$}

Микола Васильович НАБОК кандидат педагогічних наук, дочент, вчений секретар Відділення вищої освіти Національної академії педагогічних наук України, м. Київ, Україна

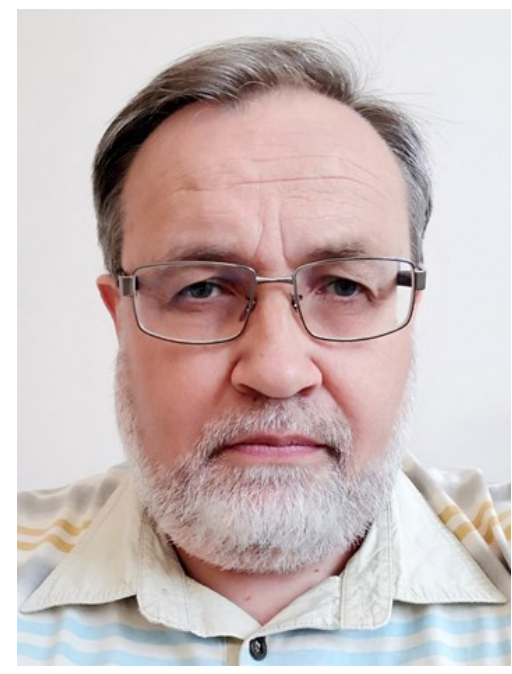

\section{КІЗІЛОВ Олександр Іванович} кандидат соціологічних наук, старший науковий співробітник, завідувач кафедри методів сочіологічних досліджень соиіологічного факультету, директор Центру сочіально-гуманітарних досліджень Харківського національного університету імені В.Н. Каразіна, м. Харків, Україна

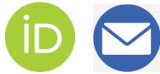

Ірина Іванівна КУЗІНА кандидат соціологічних наук, дочент, доцент каредри методів сочіологічних досліджень сочіологічного факультету Харківського національного університету імені В.Н. Каразіна, м. Харків, Україна

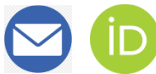

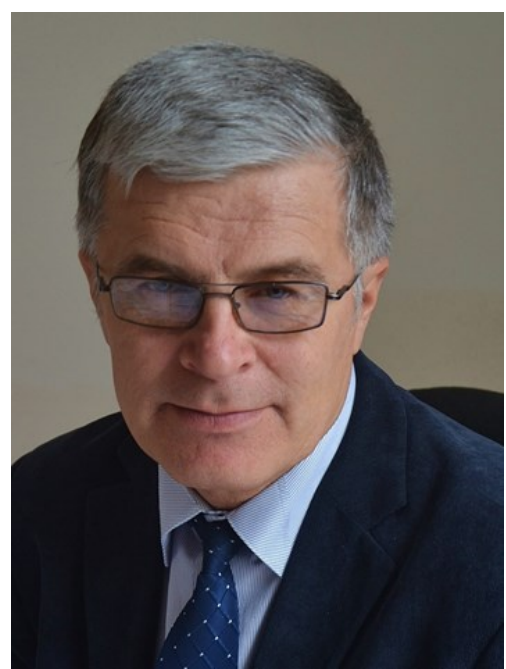

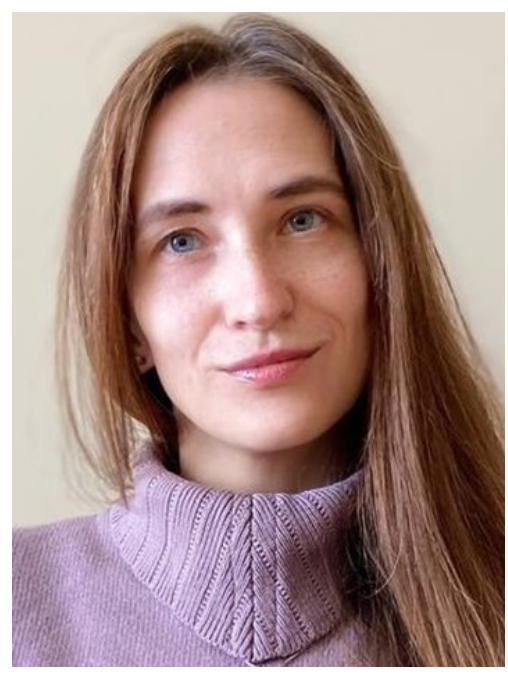


Анотація. Стаття є науково обгрунтованим результатом аналізу даних маситабного дослідницького проєкту "Студенти закладів вищої освіти про своє навчання», що його реалізовували упродовж лютого листопада 2021 р. Центр інноваційного розвитку вищої освіти Національної академії педагогічних наук України та Центр соціально-гуманітарних досліджень Харківського національного університету імені В.Н. Каразіна. Використана методологія та методика збору інформації, параметри вибіркової сукупності загалом відображають модель генеральної сукупності і відповідають вимогам репрезентативності, що $\epsilon$ підставою поширювати висновки здійсненого дослідження на всю генеральну сукупність студентів закладів вищої освіти України.

На основі системного аналізу результатів соціологічного дослідження визначено не лише сильні сторони освітнього процесу, а й істотні больові точки в роботі закладів вищої освіти різних регіонів України. На цій основі запропоновано низку заходів, пов'язаних із продукуванням практичних навичок і вмінь в освітньому прочесі, з рівнем залученості студентів до науково-дослідної та науково-пошукової роботи, академічною мобільністю, критеріями оцінювання знань, проблемами працевлаштування та протидією тенденціям міграції інтелектуального капіталу України. Окреслені в дослідженні пропозиції дають змогу органам законодавчої та виконавчої влади, роботодавиям, керівникам закладів вищої освіти зробити відповідні коригувальні кроки та ухвалити обгрунтовані рішення щодо подальших дій у реформуванні системи вищої освіти в короткостроковій та середньостроковій перспективі.

Ключові слова: середньостатистичний соціальний портрет студента; якість вищої освіти; умови навчання; виробнича практика; академічна мобільність; прачевлаштування; міграційні настрої.

Вища освіта України нині переживає складний період змін, зумовлений стратегією реформування в короткостроковій та середньостроковій перспективі, а також впливом пандемії COVID-19. Така ситуація змушує Кабінет Міністрів України, Міністерство освіти і науки України, інші центральні органи виконавчої влади та менеджмент закладів вищої освіти (далі - ЗВО) вживати адекватних дій. Зазначимо, що прийняті Урядом рішення щодо встановлення карантинних обмежень, введення «зелених», «жовтих», «помаранчевих» або «червоних» зон, виділення та порядок використання коштів на забезпечення закладів освіти антисептичними засобами, визначення умов роботи закладів освіти у звичайному або дистанційному режимі за наявності відповідного відсотка вакцинованих працівників та інші заходи істотно вплинули насамперед на безпеку учасників та організацію освітнього процесу (Кабінет Міністрів України, 2020).

Рекомендації Міністерства освіти і науки України, Міністерства цифрової інформації України та Міністерства охорони здоров'я України щодо організації дистанційного, очного та змішаного навчання, умов його організації, зокрема завершення і початку навчального року, унормування процесу використання засобів індивідуального захисту у всіх закладах освіти, обладнання санітарних кімнат, віднесення учителів та інших працівників закладів освіти до пріоритетної групи для вакцинації, проведення інформаційної кампанії щодо алгоритму вакцинування, доступних вакцин, розвінчування міфів тощо спонукали учасників освітнього процесу ЗВО до швидшої вакцинації, а самі заклади освіти до переходу переважно на дистанційну форму організації освітнього процесу
(Кабінет Міністрів України, 2020). Вжиті заходи гарантували безпеку й оптимальні умови навчання та праці учасникам освітнього процесу в умовах продовження пандемії та карантинних обмежень, деякою мірою мінімізувавши ризики поширення хвороби у закладах освіти й забезпечуючи ії доступність, однак зумовили і певне зниження якості освіти загалом (Головний державний санітарний лікар України, 2021).

Спричинені пандемією і карантином глобальні зміни в освіті спонукають Міністерство освіти і науки України вибудовувати освітню політику 3 урахуванням цих змін та необхідності реалізації стратегічних завдань з реформування вищої освіти зокрема, а керівництво ЗВО - адаптувати освітній процес до роботи зі значно ширшим та інтенсивнішим використанням змішаної та дистанційної форм навчання (Міністерство освіти і науки України, 2021). Невід'ємним елементом ефективної реалізації управлінських стратегій і політик $\epsilon$ використання зворотного зв'язку, на підставі даних якого визначають зміни ситуації, аналізують отриману інформацію про хід виконання робіт, приймають коригувальні рішення, оцінюють роботу виконавців тощо. Класичним механізмом реалізації принципу зворотного зв'язку в управлінні загалом і вищою освітою зокрема є вивчення громадської думки учасників освітнього процесу.

Із червня по вересень 2021 р. проведено анонімне онлайн-опитування, у якому взяли участь понад 2,7 тис. студентів бакалаврату та магістратури 39 закладів вищої освіти усіх регіонів України (4 - Київ, 6 - Центральний регіон, 2 - Північний, 3 - Південний, $10-$ Східний, 12 - Західний та 2 - переміщені університети). 3 них 2,7 тис. студентів навчаються у державних 3ВО, 
53 студенти - у приватних (Бакиров, Кизилов \& Даниленко, 2017).

Метою дослідження визначено вивчення проблем трансформації вищої освіти України в сучасних умовах. Об'єкт дослідження: студенти бакалаврату та магістратури закладів вищої освіти. Предмет дослідження - якість вищої освіти.

За допомогою соціологічного опитування досліджено:

- чинники, що зумовили вступ до ЗВО для отримання вищої освіти, вибір певного закладу та факультету;

- загальну оцінку навчання у ЗВО та оцінку окремих складників освітнього процесу (якість викладання, умов навчання тощо);

- оцінку якості викладання на факультеті, методик та засобів викладання, рівень комунікації з викладачами, залученості до наукової діяльності, оцінку організації та проходження виробничої і педагогічної практики, працевлаштування, відповідності освіти сучасним вимогам ринку праці, студентської мобільності та володіння іноземними мовами, міграційних настроїв та планів на майбутнє.

\section{1. Соціальний портрет студентів}

Соціально-економічний портрет українського студентства має бути предметом значно масштабнішого дослідження, однак і отримані дані опитування дають змогу в загальних рисах скласти профіль середньостатистичного студента та описати умови його життя.

Зокрема, серед опитаних студентів 917 (33 \%) юнаки і понад 1,8 тис. (67 \%) - дівчата. Середній вік складає 19,7 років. Серед них навчається для отримання освітнього рівня бакалавра більше 2,0 тис. (74 \%) студентів, магістра - 685 (25\%) студентів. Для отримання освітнього рівня спеціаліста за наскрізними освітніми програмами медичних спеціальностей навчається 34 (1 \%) студенти. У державних 3 ВО навчається понад 2,7 тис. (98 \%) студентів, у приватних навчається 53 (2 \%) студенти. $63 \%$ студентів державних 3ВО здобувають вищу освіту на бюджетній основі, а 37 \% студентів - на контрактній.

Серед галузей знань, за якими студенти здобувають вищу освіту, переважають гуманітарні науки, освіта, педагогіка, поведінкові науки, соціальна робота, журналістика, медіа, юриспруденція, право (42 \% від загальної кількості); на другому місці - медицина, охорона здоров'я, інформаційні технології, бізнес, управління, економіка, архітектура, будівництво, виробництво та техно- логії (38 \%); на третьому місці - природничі науки, математика та статистика, сільське господарство, сфера обслуговування, ветеринарія (12\%), інші галузі знань - 8 \%. За результатами останньої на момент опитування сесії більша частина студентів навчається на «добре» і «відмінно», круглих відмінників серед опитаних - приблизно чверть (24\%). Академічна успішність студентів за профільними і непрофільними предметами приблизно однакова. У порівнянні зі студентами, що навчаються на контрактній основі, помітно кращі результати навчання мають студенти, які навчаються на бюджетній основі. Існує різниця в академічній успішності студентів ЗВО з різних регіонів, порівняно успішнішими є студенти, які навчаються в Києві та в Північному регіоні.

Свій матеріальний стан студенти оцінюють таким чином: $36 \%$ вважають, що в основному грошей вистачає, однак важко придбати товари тривалого вжитку (телевізор, холодильник, меблі тощо); 39 \% вважають, що життя забезпечене, однак вони не в змозі здійснити окремі коштовні покупки (квартиру, автомобіль тощо); 7 \% вважають, що вони забезпечені повністю і мають змогу придбати практично все, а 2 \% зазначають, що їм грошей не вистачає навіть на найнеобхідніші продукти.

Основними джерелами доходу для $65 \%$ опитаних студентів є допомога батьків; для 45 \% власний заробіток; для 39 \% - стипендія.

44 \% студентів живуть з батьками, родичами; 39 \% - у гуртожитку; 15 \% винаймають кімнату, квартиру; 8 \% проживає у власному житлі.

$71 \%$ студентів не змінили місце проживання із введенням карантинних обмежень; $6 \%$ змінили місце проживання, однак залишилися в місті розташування 3ВО; $23 \%$ змінили місце проживання та виїхали з міста, у якому розміщений їхній ЗВО.

Серед опитаних студентів до вступу у ЗВО 11 \% проживали у Києві; 38 \% - в обласних центрах та містах з населенням понад 100 тис. жителів; $21 \%$ - в інших містах з населенням від 50 тис. до 100 тис. жителів та містах з населенням менше 50 тис. жителів; 30 \% проживали у селах та селищах міського типу.

II. Bступ до закладу вищої освіти (мотивація отримання вищої освіти, чинники вибору закладу вищої освіти, чинники вибору факультету / спеціальності тощо)

Найпоширенішою причиною вступу до 3 ВО $€$ бажання отримати знання і стати хорошим фахів- 
цем. Так вважають 66 \% студентів, водночас на Заході України цей відсоток сягає 77 \%. Другою причиною $є$ бажання разом з дипломом про вищу освіту знайти хорошу, престижну роботу, таких $€ 42$ \% серед опитаних. Серед студентів Києва ця частка дещо вища і складає 48 \%. Третина опитаних (35 \%) вважає, що вища освіта забезпечує і більший заробіток. Серед опитаних Центрального регіону та Києва так вважають 41 \% студентів. Таким чином, попри поширені нарікання на якість освіти, самі студенти все ще сприймають ії як засіб отримати необхідні знання, стати хорошим фахівцем та досягти успіху в майбутньому.

Вибір певного закладу освіти за бажанням навчатися в місті його знаходження або тому, що в закладі $€$ потрібна спеціальність, характерний для $41 \%$ опитаних. Серед студентів Києва так вважають 50 \% опитаних. Вибір факультету найчастіше зумовлений інтересом до майбутньої професії (61\%).

75 \% студентів обрали 6 свій 3ВО знову, 78 \% обрали б свій факультет та 76 \% обрали б повторно свою спеціальність. У ЗВО Північного регіону ця частка значно вища й складає 82 \% та вище серед опитаних. Більше схильні повторити свій вибір студенти першого курсу та магістранти.

III. Загальна оцінка навчання у закладах вищоі ocвimu

$62 \%$ студентів з різною мірою впевненості свідчать про те, що їх задовольняє рівень якості освіти, а 33 \% незадоволені лише окремими аспектами навчання. Порівняно більше задоволені навчанням студенти-першокурсники, а також студенти-магістранти.

Досить позитивно оцінюють студенти організацію освітнього процесу у ЗВО майже за всіма запропонованими критеріями. Особливо позитивно оцінюється якість викладання профільних навчальних дисциплін. Менше задоволені студенти методами викладання інтернет-комунікацій та комп'ютерних технологій, а також якістю виробничої практики.

Переважно задоволені студенти й умовами навчання. Найкращою є ситуація із забезпеченням книгами, підручниками, методичними посібниками та науковою літературою. Також майже всі студенти мають можливість для занять фізкультурою і спортом у ЗВО. Найбільше негативних оцінок дають студенти якості інтернет-зв'язку і загалом доступу до інтернету та забезпеченості Wi-Fi.
Існує певна розбіжність в оцінці задоволеності якістю навчання у ЗВО різних регіонів. Зокрема, більше задоволені студенти Північного і Центрального регіонів, дещо менше задоволені студенти, які навчаються у ЗВО Сходу і Півдня України.

IV. Оцінка якості викладання на фракультеті (методика, засоби навчання, комунікація з викладачами тощо)

Якість викладання профільних і непрофільних дисциплін за 10-бальною шкалою оцінюється від 7 до 10 балів. Середня оцінка якості викладання складає 7,9 бала. Найвищі оцінки якості викладання дають студенти першого і останніх (5-6) курсів. Існує різниця в оцінках студентів з різних регіонів: вищі оцінки отримано у Північному, Центральному та Західному регіонах, порівняно нижчі - у Києві.

Абсолютна більшість студентів зазначає, що в освітньому процесі викладачі застосовують новітні методики-презентації в електронному вигляді, використовують інтернет-контент, онлайн-сервіси, відеоконференції тощо. Для організації навчання викладачі ЗВО використовують різні засоби цифрової комунікації. Водночас 30 \% студентів вказують на застарілість матеріалу, брак нової наукової інформації в програмах навчальних курсів. Нерідко матеріал викладачі подають, диктуючи студентам конспекти лекцій. Крім цього, кожен четвертий студент незадоволений ставленням викладачів до студентів, рівнем наявної комунікації.

V. Рівень залученості до науково-дослідної poбomu

Більшість студентів виявляє цікавість до наукової діяльності. Про це заявляє 69 \% опитаних. Однак відсоток тих, хто цікавиться наукою, тому що планує у майбутньому стати науковцем, коливається на різних курсах навчання від $21 \%$ до $26 \%$ у магістратурі. Орієнтація на аспірантуру для студентів бакалаврату складає 12-15 \%, а для магістрантів - $25 \%$.

Певним індикатором наукової активності студентів $€$ наявність наукових публікацій у фахових виданнях та участь у наукових конференціях. Наукові публікації має майже четверта частина опитаних студентів (24\%), досвід участі у наукових конференціях - 39 \%. 50 \% магістрантів мають публікації та досвід участі у наукових конференціях. Незважаючи на те, що ЗВО беруть участь у міжнародних освітніх та наукових проєктах, про що відомо більшості опитаних студентів (67\%), їхня персональна участь у цих проєктах доволі 
низька, вона складає, зокрема, для студентів молодших курсів 2-3 \% і 9-10 \% для старшокурсників.

VI. Якість організації та проведення виробничої і педагогічної практик

Абсолютна більшість студентів (70 \%) задоволена організацією та проведенням практики й зазначає, що вона відповідала обраній спеціальності. 18 \% опитаних зазначили, що практика мала лише формальний характер, тобто їі фактично не було. Серед проблем, з якими зіткнулися студенти під час проходження практики, є застарілість робочого місця практики, обмеженість зв'язків ЗВО з роботодавцями. Крім того, студентів дратує дуже велика кількість документів, які потрібно готувати під час проходження практики. До того ж студенти вважають, що ЗВО мало дбають про підвищення конкурентоспроможності своїх випускників на ринку праці. На їхню думку, в освітньому процесі необхідно приділяти більше уваги практичним навичкам і вмінням, ширше залучати до викладання фахівців-практиків, а також збільшити обсяг практики, впроваджувати стажування студентів. Важливо також збільшення обсягу викладання іноземних мов та орієнтація у викладанні на сучасні інформаційні технології.

\section{VII. Працевлаштування}

Результати опитування свідчать, що 67 \% студентів мають досвід роботи поза навчанням, половина студентів на час опитування працюють, працевлаштовані на повну або часткову зайнятість - 32 \%. На старших курсах працює переважна більшість опитаних. Однак більшість опитаних, а це $55 \%$, працює не за фахом. Найбільший досвід роботи за фахом мають студенти галузей журналістика, медіа, інформаційні технології, бізнес, управління, економіка.

76 \% студентів вважають, що у ЗВО вони отримують знання і навички, необхідні для майбутньої професії. На їхню думку, якість освіти відповідає сучасним вимогам ринку праці. Впевненіші в цьому студенти, які здобувають освіту у сфері природничих та поведінкових наук, у галузі освіти й педагогіки. Шанси знайти роботу в Україні за фахом студенти оцінюють невисоко. 40 \% опитаних вважають, що це складно, 40 \% вагаються, а 20 \% вважають, що це неможливо. Найлегше знайти роботу студентам IT-спеціальностей, найскладніше - юристам.

Студенти зазначають, що ЗВО намагаються допомогти з працевлаштуванням. Така допомога полягає в організації стажування та виробничої практики. Також студенти отримують корисні по- ради від викладачів, керівників факультетів. Четверта частина залучених 3 ВО проводить ярмарки вакансій, у 22 \% 3ВО працюють центри або відділи з працевлаштування студентів і випускників. Водночас студенти переконані, що ЗВО мають тісніше співпрацювати з роботодавцями над створенням певних навчально-виробничих комплексів тощо.

VIII. Оцінка студентської мобільності ma рівня володіння іноземною мовою

Більшість опитаних студентів (88 \%) відповіла, що володіє на певному рівні іноземною мовою. Найпопулярнішою серед іноземних мов є англійська. $16 \%$ володіють німецькою мовою, 7 \% польською, 5 \% - французькою. Англійською мовою володіють $90 \%$ студентів, що навчаються в Києві, а польською володіють більше студенти ЗВО Західного регіону. Однак сертифікат про знання іноземної мови мають лише $16 \%$ студентів.

У майже половини студентів є друзі або знайомі за кордоном, з якими вони підтримують зв'язки та спілкуються. Особливо це характерно для студентів Києва та Західного регіону, менше - для Північного регіону та студентів, які до вступу до ЗВО мешкали в селах.

Більше половини студентів не володіють інформацією, чи викладають у їхньому ЗВО окремі предмети іноземною мовою. Не знають студенти й того, чи викладають у їхньому виші іноземні викладачі.

Половина студентів зазначила, що вони виїжджали за кордон. Однак це зовсім не пов'язано з академічною мобільністю. Здебішого причиною закордонних подорожей є туризм. Найчастіше подорожували студенти з Києва та Західного регіону до Польщі, Німеччини, Туреччини.

IX. Плани на майбутнє, міграційні настрої

Більше половини студентів-бакалаврів бажають продовжити навчання в магістратурі, переважно - у своєму ЗВО. 25 \% опитаних заявили, що після закінчення бакалаврату навчання не продовжуватимуть. Виїхати для навчання за кордон має намір $28 \%$ опитаних. Працювати за кордоном на тимчасовій роботі бажають $38 \%$ студентів, а 24 \% планують виїхати за кордон на постійне місце проживання. Найвагомішою причиною виїзду за кордон студенти називають вищий матеріальний рівень життя та більше можливостей для самореалізації. Водночас третина студентів не планує зовсім виїжджати за кордон, аргументуючи це тим, що в Україні вони мають усі можливості для самореалізації. 
Висновки. Результати проведеного дослідження свідчать, що студентство під час другої хвилі пандемії та запровадження дистанційного навчання в різних його формах загалом успішно адаптувалося до нових умов. На противагу емоційним судженням деяких експертів та політиків, результати соціологічного дослідження підтверджують достатньо високу якість вищої освіти в Україні (Саух, 2021). Абсолютна більшість студентів усвідомлює, навіщо їм потрібна вища освіта, і знає, як ії монетизувати в якісне майбутнє життя.

За оцінками студентів, високим є рівень викладання профільних і непрофільних дисциплін. Переважна більшість студентів відзначає, що в освітньому процесі застосовуються новітні методики викладання та практикуються різноманітні засоби цифрової комунікації. Опитування засвідчує, що найбільш поширене проведення онлайнзанять здійснюється за допомогою платформи Zoom, рідше - Google Meet, а комунікація викладачів зі студентами часто відбувається у групах за допомогою двох найпопулярніших додатків Viber i Telegram. Для організації дистанційного освітнього процесу, управління ним та забезпечення взаємодії між викладачем та студентами застосовуються системи управління навчанням MOODLE та Google Classroom.

Достатньо позитивно оцінюють студенти створені в університетах умови для навчання, забезпеченість навчальною та науковою літературою, організацією і проведенням виробничих і педагогічних практик, залучення їх до наукової діяльності. Очевидно, саме тому студенти переважно задоволені своїм навчанням у ЗВО. Більшу задоволеність навчанням показують студенти Північного і Центрального регіонів, дещо менше задоволені студенти Сходу і Півдня України. Абсолютна більшість опитаних студентів обрала 6 свій 3 ВО знов.

Загалом результати соціологічного дослідження опосередковано свідчать, що очевидна незворотність змін актуалізувала питання автономії 3ВО, особливо в академічному, організаційному та кадровому вимірах (Закон України «Про вищу освіту», 2014). Ідеться насамперед про підвищення рівня самостійності у питаннях набору студентів, вибору навчальних програм, змісту і форм навчання, загалом вжиття різних заходів з метою недопущення зниження якості освіти. Водночас ці зміни спонукали керівництво ЗВО до вдосконалення та оптимізації організаційних структур управління закладами, до пошуку нових та вдосконалення чинних механізмів оцінювання результа- тивності роботи науково-педагогічних працівників, особливо з огляду на рівень володіння і застосування в освітньому процесі інформаційнокомунікаційних технологій у дистанційному навчанні (Державна служба якості освіти України, 2021).

Водночас третина студентів звертає увагу на застарілість матеріалу, що викладається, на брак новітньої наукової інформації у навчальних курcax, на примітивність лекцій «під диктовку». В університетах не скрізь відчувається сприяння розвитку цифрової освіти (інфраструктура, зв'язок, технічні засоби, розвиток компетенцій викладачів, високоякісний контент). Зокрема, незадоволені студенти якістю інтернет-зв'язку у ЗВО та обмеженістю доступу до мережі за допомогою $\mathrm{Wi}-\mathrm{Fi}$.

Викликає занепокоєння оцінка, що ії дають студенти рівню залученості їх до науководослідної та науково-пошукової роботи, яка нерідко будується на власних ініціативах. Не менш важливою, хоч і спричиненою пандемією та карантином, є низька академічна мобільність - як внутрішня, так і міжнародна.

Незважаючи на загальну позитивну оцінку організації виробничих практик, абсолютна більшість студентів вважає, що ЗВО недостатньо дбають про підвищення конкурентоспроможності своїх випускників на ринку праці. Вони переконані, що в освітньому процесі необхідно більше часу приділяти формуванню практичних навичок і вмінь, значно збільшити обсяги практики, ширше впроваджувати стажування студентів на виробництві, залучати до педагогічної діяльності викладачів-практиків. Крім того, студенти незадоволені великою кількістю документів, які необхідно заповнювати під час проходження практики. Значна частина студентів зазначає, що практика в їхніх ЗВО здебільшого є формальною, тобто ії практично не існує. Половина опитаних студентів вважає, що університет має дати глибокі професійні навички, які б дали їм змогу успішно працювати за фахом.

Кожен четвертий студент незадоволений ставленням викладачів до них, відсутністю комунікації між ними й викладачами. Існує немало скарг на необ'єктивність чинної системи оцінювання навчальних досягнень, упередженому ставленні до студентів, недоброчесному виконанні поставлених завдань. Загалом оцінювання знань, на думку студентів, є незрозумілим для них та без чітко визначених критеріїв.

З огляду на зазначене, є підстави стверджувати: 
По-перше, освітній процес у ЗВО вимагає посилення його практико орієнтованого спрямування. 3ВО не стали джерелом інжинірингових послуг та центрами консалтингового сервісу для суб'єктів ринку праці. Важливим кроком у вирішенні цієї проблеми могло б бути створення освітньо-промислових груп ЗВО і підприємств (Саух, 2020). Це 6 сприяло розширенню практики соціального партнерства з компаніями-роботодавцями, залученню їх до розроблення навчальних програм, розвитку soft-skills студентів шляхом продукування відповідних програм, залучення представників компаній до проведення занять (читання лекцій, проведення майстер-класів), запровадження програм стажування викладачів в компаніях для набуття та удосконалення практичного досвіду. Для того, щоб вирішити цю проблему, в регіонах України слід впровадити систему грантової підтримки інноваційних проєктів, результатів соціально та економічно значущих прикладних наукових досліджень в університетах, що сприятиме формуванню фінансово-ресурсного забезпечення зайнятості і самозайнятості молодих фахівців.

По-друге, значно більше уваги потребує налагодження співпраці ЗВО із зарубіжними університетськими центрами з метою залучення їх викладачів до освітнього процесу, реалізації спільних наукових проєктів, розширення можливостей академічної мобільності викладачів та студентів за умов карантинних обмежень, впровадження практики викладання окремих курсів іноземною мовою (Кізілов, Рапопорт \& Кізілова, 2014). Наявний рівень володіння іноземними мовами, отримання навичок майбутніх професій, комунікації студентів і викладачів звужує можливості доступу до світових освітньо-наукових і культурних надбань та знижує конкурентоспроможність на ринку праці.

По-mpemє, потребує значного зміцнення матеріально-технічна база освітнього процесу у 3ВО, особливо в контексті цифровізації освіти та організації якісного дистанційного навчання. Не менш важливим є підвищення цифрової компетенції викладачів, які в умовах пандемії іноді перестали навчати й нерідко обмежуються постановкою завдань і перевіркою їх виконання. В університетах має бути розроблена певна програма психологічної підтримки учасників освітнього процесу в умовах карантинних обмежень та переходу на різні форми дистанційного навчання.

По-четверте, очевидною є також проблема менеджменту навчального часу, тобто перегляду навчальних планів з огляду на їх реалізацію в умовах дистанційного навчання, корегування типів і кількості завдань, які реально можна виконати і перевірити, встановлення часових обмежень на роботу за комп'ютером для викладача і студента, поділ завдань на синхронні (у режимі реального часу на зустрічах в Zoom, MS Teams, Google Meet та ін.) й асинхронні (домашні завдання), надання конкретних інструкцій для їх виконання, підбір відповідних онлайн-інструментів тощо.

По- $n$ 'яте, ЗВО повинні істотно вдосконалити систему виховної роботи, забезпечивши синергію навчання і виховання. І робити це потрібно не вимиванням гуманітарного складника освітнього процесу, а його посиленням (Саух \& Саух, 2021). збільшення в останні роки кількості студентів, що виїжджають на навчання за кордон, нерідко зумовлене не так відсутністю академічної мобільності, як еміграційними настроями. Для реалізації завдань кадрової політики держави та підвищення рівня ефективності протидії загрозам національній безпеці Міністерству освіти і науки України та Міністерству соціальної політики України доцільно створити Міжвідомчу раду з питань протидії тенденціям міграції інтелектуального капіталу.

\section{СПИСОК ВИКОРИСТАНИХ ДЖЕРЕЛ}

Бакиров, В.С., Кизилов, А.И., \& Даниленко, И.В. (2017). Онлайн-опрос в системе социологического мониторинга высшей школы Украины. Вісник Харківського національного університету імені В.Н. Каразіна. Серія «Сочіологічні дослідження сучасного суспільства: методологія, теорія, методи», (39), 275-280. https://periodicals.karazin.ua/ssms/article/view/10256

Головний державний санітарний лікар України. (2021, 23 квітня). Про затвердження протиепідемічних заходів у закладах освіти на період карантину у зв'язку з поширенням коронавірусної хвороби (COVID-19) (4). https://bit.ly/3qvEIOz

Державна служба якості освіти України. (2021). Аналітична довідка щодо тендениій організації дистаниійного навчання у закладах фахової передвищої та вищої освіти в умовах карантину у 2020/2021 навчальному році (за результатами онлайнанкетування учасників освітнього прочесу). https://bit.ly/3fvXui5

Закон України «Про вищу освіту». (2014, 1 липня). https://zakon.rada.gov.ua/laws/show/1556-18

Кабінет Міністрів України. (2020, 9 грудня). Про встановлення карантину та запровадження обмежувальних протиепідемічних заходів з метою запобігання поширенню на території України гострої респіраторної хвороби COVID-19, спричиненої коронавірусом SARS-CoV-2. (1236) https:// zakon.rada.gov.ua/laws/show/1236-2020-п

Кабінет Міністрів України. (2021, 3 вересня). Про внесення змін до постанов Кабінету Міністрів України від 9 грудня 2020 р. № 1236 і від 29 червня 
2021 p. № 677 (954). https://zakon.rada.gov.ua/laws/ show/954-2021-п

Кізілов, О., Рапопорт, А., \& Кізілова, К. (2014). Академічна мобільність українських студентів: наміри, залучення та перешкоди. Методологія, теорія та практика соціологічного аналізу сучасного суспільства, (20), 327-334.

Кузіна, І. (2017). Роль інституту освіти в забезпеченні інформаційної безпеки держави (з позицій неоінституціонального підходу). Вісник Харківського національного університету імені В.Н. Каразіна. Серія «Соціологічні дослідження сучасного суспільства: методологія, теорія, методи», (38), 31-34. https://periodicals.karazin.ua/ssms/article/view/8573

Міністерство освіти і науки України. (2021, 21 жовтня). Про організацію освітнього прочесу в закладах освіти під час епідемічної небезпеки (1/9-558). https://bit.ly/3Ka3kUH
Cаух, П.Ю. (2020). Стратегічне бачення нової моделі вищої освіти: рух до створення університетів світового класу. Наукова доповідь на методологічному семінарі НАПН України "Шляхи і механізми підвищення конкурентоспроможності університетів України» 19 листопада 2020 р. Вісник Національної академії педагогічних наук України, 2(2). https:// doi.org/10.37472/2707-305X-2020-2-2-13-7

Cayx, П. (2021). Вища освіта: портрет без фантазій і прикрас. Вища освіта України, (1), 13-19.

Саух, П.Ю., \& Саух, І.В. (2021). Духовність у «колесі життєвого балансу» сучасної людини. Вісник Начіональної академії педагогічних наук України, 3(2). https://doi.org/10.37472/2707-305X-2021-3-2-14-2

World Bank Group. (2021, 2 April). The Impact of COVID19 on Education - Recommendations and Opportunities for Ukraine. https://bit.ly/3ftPpe4

\title{
THE QUALITY OF HIGHER EDUCATION IN UKRAINE THROUGH THE EYES OF STUDENTS
}

\author{
Petro Saukh \\ DSc in Philosophy, Professor, Full Member (Academician) of NAES of Ukraine, Academician Secretary of \\ the Division of Higher Education, National Academy of Educational Sciences of Ukraine, Kyiv, Ukraine \\ Mykola Nabok \\ PhD in Pedagogy, Associate Professor, Scientific Secretary of the Division of Higher \\ Education, National Academy of Educational Sciences of Ukraine, Kyiv, Ukraine \\ Oleksandr Kizilov \\ PhD in Sociology, Senior Researcher, Head of the Department of Methods of Sociological \\ Research of the Faculty of Sociology, Director of the Social and Humanitarian Research \\ Centre, V.N. Karazin Kharkiv National University, Kharkiv, Ukraine \\ Iryna Kuzina \\ PhD in Sociology, Associate Professor, Associate Professor of the Department of Methods of Sociological \\ Research of the Faculty of Sociology, V.N. Karazin Kharkiv National University, Kharkiv, Ukraine
}

Abstract. The paper is the scientifically substantiated result of analysing the large-scale research project data "Students of Higher Education Institutions about Their Studies", realised during February-November 2021 by the Centre for Innovative Development of Higher Education of the National Academy of Educational Sciences of Ukraine and Social and Humanitarian Research Centre of V.N. Karazin Kharkiv National University. The methodology and methods of collecting information are used; the parameters of the selection set as a whole reflect the common set model and meet the requirements of representativeness, which allows extending the findings to the common set of higher education institutions' students in Ukraine.

By providing a systematic analysis of the sociological research results, the educational process strengths were identified, and current issues in the work of higher education institutions in different regions of Ukraine were explored. On this basis, a number of measures related to the production of practical skills and abilities in the educational process, with the level of student involvement in research and development work, academic mobility, criteria for assessing knowledge, employment problems, and counteracting the trends of migration of intellectual capital of Ukraine. The proposals outlined in the research allow the legislative and executive bodies, employers, and heads of higher education institutions to take appropriate corrective steps and make substantiated decisions on further actions in reforming the higher education system in the short and medium-term.

Keywords: average social portrait of a student; quality of higher education; conditions of studies; industrial practice; academic mobility; employment; migratory moods. 